\title{
Plasmids in throat and genital isolates of meningococci
}

\author{
CA ISON, CM BELLINGER, AA GLYNN* \\ From the Microbiology Department, St Mary's Hospital Medical School, London W2, and the *Central \\ Public Health Laboratory, Colindale, London NW9
}

SUMMARY Plasmids $1 \cdot 6,2 \cdot 8$, or $>40$ megadaltons in size were found in one urethral and nine throat strains of meningococci. Throat meningococci are known to be heterogeneous in their aminopeptidase profiles. Their unexpected content of plasmids is further evidence of their difference from classic systemic strains. Although the 2.8 megadalton plasmid has some resemblance to the well known 2.6 megadalton gonococcal plasmid, restriction enzyme studies gave no evidence of identity. Possible sources of the plasmids are discussed.

Pharyngeal carriage of meningococci is increased in patients attending sexually transmitted disease clinics. ${ }^{1}$ Carriage is particularly prevalent in male homosexuals, in whom the rate may be as high as $41 \% .^{2}$ Two explanations have been suggested: promiscuity within a relatively closed community encouraging spread of neisseria or undue susceptibility to neisseria in some patients.

We have put forward a third possibility: that some strains of Neisseria gonorrhoeae may have been transformed to utilise maltose by DNA from normal throat flora and have therefore been misidentified as meningococci. ${ }^{3}$ Evidence was presented that the maltase gene could be transformed into gonococci in vitro from other neisseria. The meningococci isolated from the throats of male homosexuals also differed from systemic meningococci in their aminopeptidase profiles. They were a more heterogenous group than the systemic isolates and included some meningococci which, though they utilised maltose, gave typical gonococcal aminopeptidase profiles. This again posed the question whether some meningococci differentiated from gonococci by carbohydrate utilisation alone could, in fact, be gonococci. At this time more than $99 \%$ of gonococci were known to carry the 2.6 megadalton cryptic plasmids. Other plasmids, the 24.5 megadalton conjugal plasmid and the 4.4 and 3.2 megadalton $\beta$ lactamase plasmids, are present only in some strains. In contrast, no meningococci were thought to carry plasmids. ${ }^{4}$ Four recent reports of single plasmid isolation are discussed later.
In view of the potential for gene transfer between species, the aim of this work was to screen meningococci from various sources for the presence of the 2.6 megadalton plasmid, to test the hypothesis that some could be misidentified gonococci, and to examine any plasmid carrying strains for their auxotype and aminopeptidase profiles to establish their relation to gonococci.

\section{Material and methods}

STRAINS OF NEISSERIA

Twenty four strains of $N$ meningitidis originating from the blood or cerebrospinal fluid of patients with meningitis were obtained from Dr AG Taylor, Central Public Health Laboratory, Colindale.

One hundred and sixty one strains of $N$ meningitidis were isolated from the throats of male homosexuals attending the sexually transmitted diseases clinic. These strains were classified by their aminopeptidase profiles estimated qualitatively (Table 1). This does not represent the true prevalence of the different groups because selection by aminopeptidase profile or plasmid content was performed at various times.

Seven strains that split ortho-nitrophenyl galactoside to ortho-nitrophenyl were identified as $N$ lactamica.

Eleven strains of $N$ meningitidis were isolated from anogenital sites in patients attending the clinic.

Twenty three transformants that were originally gonococci and had gained either the ability to utilise maltose or glutamyl aminopeptidase activity were screened. 
Table 1 Distribution of aminopeptidase profiles in throat meningococci

\begin{tabular}{lll}
\hline \multicolumn{2}{l}{ Aminopeptidase profile } & \\
\hline Glutamyl & Hydroxyproline & No of strains (\%) \\
\hline$+^{*}$ & - & $97(60 \cdot 2)$ \\
$+_{+}^{+}$ & + & $27(16 \cdot 8)$ \\
\hline
\end{tabular}

*Typical meningococcal pattern.

tTypical gonococcal pattern.

$+=$ present; $-=$ absent .

IDENTIFICATION OF NEISSERIA

Strains were called $N$ meningitidis if they were Gram negative cocci, oxidase positive, and produced acid from glucose and maltose but not sucrose. Strains were tested for their ability to utilise different carbohydrates on serum free medium containing glucose, maltose, or sucrose poured in petri dishes. ${ }^{5}$

Their ability to utilise lactose was determined by the ortho-nitrophenyl galactoside test, which was performed as follows. The stock solution containing $0.6 \mathrm{~g} / 100 \mathrm{ml}$ of ortho-nitrophenyl galactoside (Sigma) in $0.01 \mathrm{M}$ disodium phosphate was diluted $1 / 4$ in peptone water before use. The working dilution was heavily inoculated and incubated at $37^{\circ} \mathrm{C}$ in a waterbath. A change to yellow after 5-10 min was recorded as positive; strains that utilised glucose and maltose and were ortho-nitrophenyl galactoside positive were called $N$ lactamica. Negative strains were reincubated for $1 \mathrm{~h}$ and if they changed colour were recorded as weak positive.

AMINOPEPTIDASE PROFILES

All strains were examined qualitatively for their aminopeptidase profiles as described previously. ${ }^{3}$ Glutamyl and hydroxyproline aminopeptidase was determined quantitatively in all plasmid carrying strains. $^{3}$

\section{PLASMID ANALYSIS}

Each strain was grown on one plate containing GC medium base (Difco) plus $1 \%$ Iso Vitalex (BBL) overnight at $36^{\circ} \mathrm{C}$ in $7 \% \mathrm{CO}_{2}$. The growth was suspended in saline and centrifuged, and plasmids were extracted from the pellet by the rapid method of Birnboim and Doly. ${ }^{6}$ This method entails lysis of the cells by lysozyme and sodium dodecyl sulphate, followed by selective alkaline denaturation of high molecular weight chromosomal DNA, while covalently closed circular DNA remains double stranded. Plasmid DNA, together with RNA fragments, are recovered by ethanol precipitation. Plasmids were run on $1.0 \%$ agarose gel in acetate buffer at $200 \mathrm{~mA}$ until the dye front had migrated $6-7 \mathrm{~cm}$. Plasmids were stained with ethidium bromide $(1 \mu \mathrm{g} / \mathrm{ml})$.
RESTRICTION ENZYME ANALYSIS

The plasmid extraction was carried out as above except that the final resuspension was in distilled water, not Tris-EDTA-saline buffer. Two microlitres of $1 \mathrm{mg} / \mathrm{ml}$ RNAase was added to $18 \mu \mathrm{l}$ of plasmid suspension and incubated at $37^{\circ} \mathrm{C}$ for 30 $\mathrm{min}$. To this an equal volume of digestion buffer was added, together with 10 units of restriction endonuclease $(1 \mu \mathrm{l})$. This gave an excess enzyme: DNA ratio. After a further $60 \mathrm{~min}$ at $37^{\circ} \mathrm{C}$, the reaction was stopped by cooling rapidly on ice; samples were stored at $-20^{\circ} \mathrm{C}$ until needed.

The digestion buffer consisted of $10 \mathrm{mM}$ Tris, $20 \mathrm{mM}$ magnesium chloride, $1 \mathrm{mM}$ dithiothreitol, and $10 \mu \mathrm{g} / \mathrm{ml}$ bovine serum albumin, $\mathrm{pH} 8$, for Hpa II and Msp I. The same buffer with $100 \mathrm{mM}$ $\mathrm{NaCl}$ was used for Hinf I and Ava II.

\section{AUXOTYPING}

Nutritionally deficient, chemically defined media ${ }^{7}$ were inoculated using the Denley multipoint inoculator, which delivered $1 \mu \mathrm{l}$. All strains, tested in duplicate, were incubated for $48 \mathrm{~h}$ at $36^{\circ} \mathrm{C}$ in $\mathrm{CO}_{2}$. The presence of macrocolonies was taken to indicate growth.

\section{Results}

Table 2 shows the number of plasmid carrying strains of neisseria found in each group. Of the 161 throat meningococcal strains nine carried plasmids. The plasmids found in throat strains of $N$ meningitidis and $N$ lactamica were of molecular weight $1 \cdot 6$, $2 \cdot 8$, and $>40$ megadaltons. The two low molecular weight plasmids were sometimes present in combination. One of the 11 anogenital isolates carried a plasmid of 2.6 megadaltons, and all gonococci that had been transformed to utilise maltose or gain glutamyl aminopeptidase had retained the 2.6 megadalton cryptic plasmid.

Examples of the plasmids found are compared with the 2.6 megadalton cryptic gonococcal plasmid in Fig. 1. Some faint lines are due to open circle DNA. The presence of closed circular DNA has not yet been confirmed by electron microscopy.

Table 2 Distribution of plasmids in neisseria

\begin{tabular}{lcc}
\hline & No tested & No with plasmids \\
\hline$N$ meningitidis & & \\
$\begin{array}{l}\text { Blood/cerebrospinal } \\
\quad \text { fluid }\end{array}$ & 24 & 0 \\
$\begin{array}{l}\text { Throat } \\
\text { Anogenital }\end{array}$ & 161 & 9 \\
$N$ lactamica & 11 & 1 \\
$\quad \begin{array}{l}\text { Throat } \\
\text { gonorrhoeae }\end{array}$ & 7 & 2 \\
$\quad$ Transformants & 23 & 23 \\
\hline
\end{tabular}




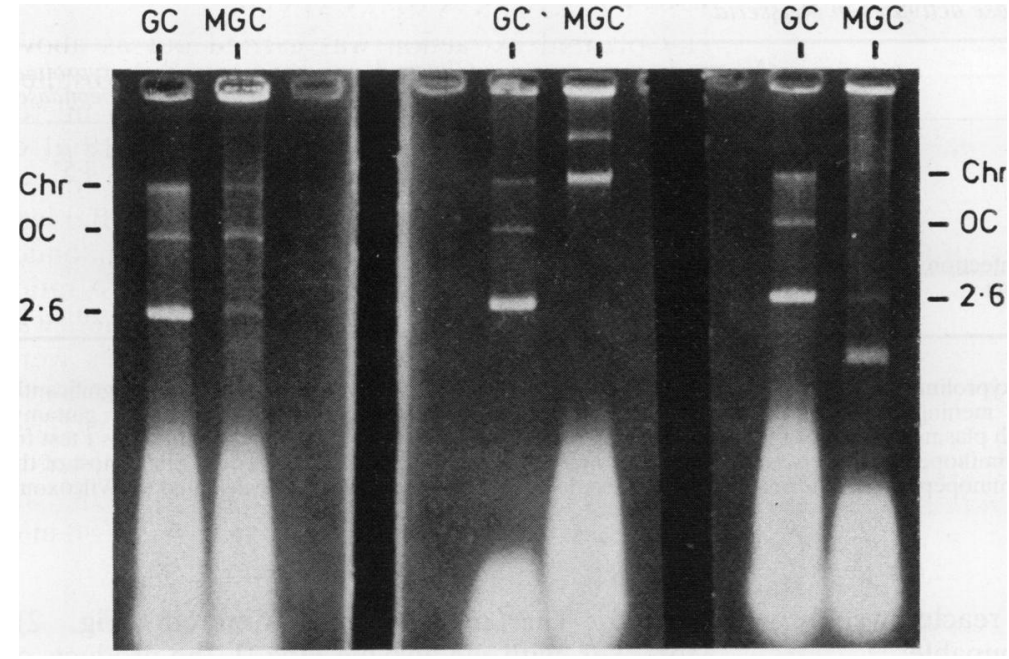

Fig. 1 Agarose gel electrophoresis of plasmids from three strains of throat meningococci compared with gonococci. All the gonococci show a 2.6 megadalton plasmid (2.6), some open circle $(O C)$ and some chromosomal (Chr) DNA. Meningococcal strain A shows a 2.8 megadalton plasmid, open circle and chromosomal DNA. Meningococcal strain B shows a 40 megadalton plasmid and open circle DNA. Meningococcal strain $C$ shows $a 1.6$ and 2.6 megadalton plasmid and chromosomal DNA.

The aminopeptidase profile and plasmid content of all plasmid carrying strains are shown in Table 3. Five of the nine throat meningococci had high levels of glutamyl aminopeptidase and low levels of hydroxyproline aminopeptidase, which approached those typical of systemic strains. The remaining four had increased levels of hydroxyproline aminopeptidase with low levels of glutamyl aminopeptidase, more like $N$ gonorrhoeae. Nevertheless, the plasmid bearing throat meningococci seemed to be an intermediate group with a continuous range of aminopeptidase values. Their mean glutamyl and hydroxyproline aminopeptidase levels differed significantly from the means found in the remaining throat meningococci, in systemic meningococci, and in gonococci (Table 4). Increasing glutamyl aminopeptidase levels were correlated significantly with decreasing levels of hydroxyproline aminopep- tidase $(p<0.01)$ (Spearman rank correlation coefficient).

All systemic and throat meningococci, including those with plasmids, were prototrophic and did not require cystine for growth. The urethral meningococcal isolate required cystine, proline, and arginine for growth. Its aminopeptidase profile was more like that of $N$ gonorrhoeae than $N$ meningitidis.

$N$ lactamica strain 160 required cystine. Both strains of $N$ lactamica had aminopeptidase profiles similar to gonococci but also to other strains of $N$ lactamica (unpublished observation). The aminopeptidase levels fell within the range of the plasmid bearing throat meningococci.

\section{SEROLOGY}

Of the nine plasmid bearing throat meningococci,

Table 3 Distribution of aminopeptidase activity in plasmid carrying strains of $N$ meningitidis and $N$ lactamica

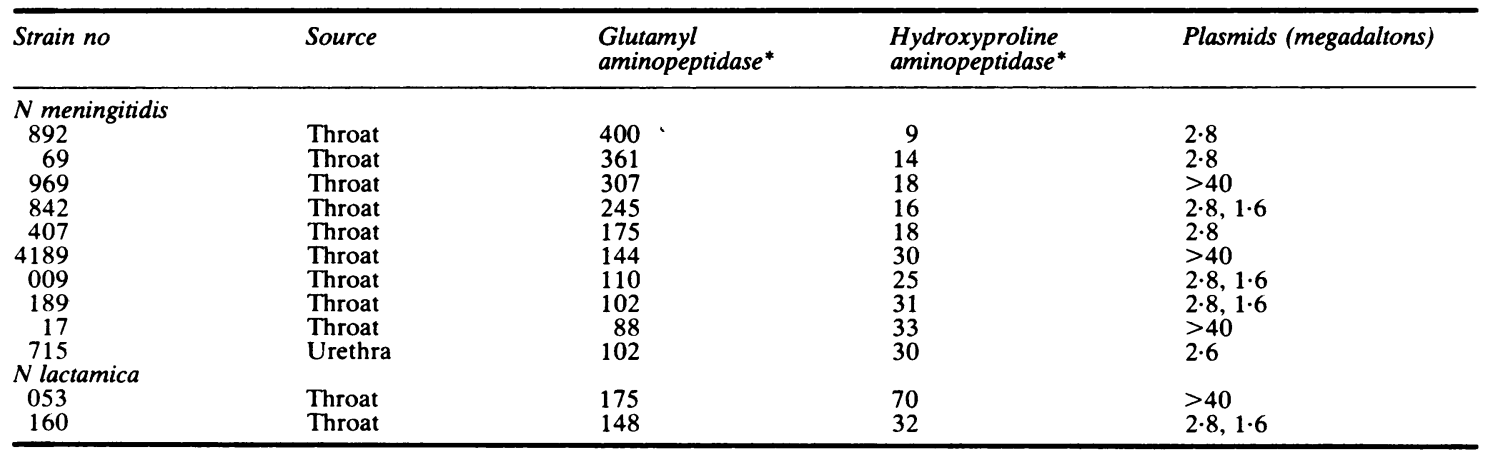

*Activity as nmols substrate converted/mg protein in original suspension. 
Table 4 Comparison of aminopeptidase activities in Neisseria

\begin{tabular}{|c|c|c|c|c|}
\hline Strain & Source & No tested & $\begin{array}{l}\text { Glutamyl } \\
\text { aminopeptidase }\end{array}$ & $\begin{array}{l}\text { Hydroxyproline } \\
\text { aminopeptidase }\end{array}$ \\
\hline $\begin{array}{l}N \text { meningitidis with } \\
\text { plasmids } \\
N \text { meningitidis no } \\
\text { plasmids } \\
N \text { meningitidis no } \\
\text { plasmids } \\
N \text { gonorrhoeae }\end{array}$ & $\begin{array}{l}\text { Throat } \\
\text { Throat } \\
\text { Systemic infection } \\
\text { Genital tract }\end{array}$ & $\begin{array}{r}9 \\
100 \\
45 \\
19 \\
39\end{array}$ & $\begin{array}{c}215 \pm 118^{*} \\
502 \pm 142 \\
640 \pm 204 \\
69 \pm 33\end{array}$ & $\begin{array}{l}21 \cdot 6 \pm 8 \cdot 5^{*} \\
3 \cdot 3 \\
0.41 \\
36 \pm 20\end{array}$ \\
\hline
\end{tabular}

Values given as mean $\pm \mathrm{SD}$.

The glutamyl aminopeptidase and hydroxyproline aminopeptidase values for the plasmid containing meningococci are significantly different from both the other groups of meningococci and from gonococci ( $p<0.001$ for all comparisons except for glutamyl aminopeptidase in throat meningococci with plasmids compared with gonococci, where $p<0.01$ ). $p$ was calculated by Student's test for all comparisons except for hydroxyproline aminopeptidase between plasmid and non plasmid-containing meningococci. Since most of the latter had zero values for hydroxyproline aminopeptidase, a normal distribution could not be assumed and p was calculated by Wilcoxon's rank test.

*Activity in same units as Table 3.

two appeared to be group B, one reacted weakly as group $\mathrm{X}$, and the rest were ungroupable.

\section{ACTION OF RESTRICTION ENZYMES}

The method of restriction endonuclease analysis was set up using the 2.6 megadalton gonococcal plasmid; patterns were obtained for the enzymes used as described by Davies and Normark. ${ }^{8}$

When the new plasmids were tested with the enzyme Hinf 1 , the 2.6 and 2.8 megadalton plasmids of strains 715 and 842 respectively gave products similar to those of the gonococcal $2 \cdot 6$ megadalton plasmid. The other strains differed (Fig. 2). Moreover, with the enzyme $\mathrm{Hpa}$ II, the products of the 715 and 842 plasmid strains were quite different from the gonococcal plasmid. Msp I and Ava II did not split any of the low molecular weight plasmids. No attempt was made to split the $>\mathbf{4 0}$ megadalton plasmids.

\section{Discussion}

Our previous work ${ }^{3}$ showed heterogeneity of throat compared with systemic meningococci. Preliminaryo

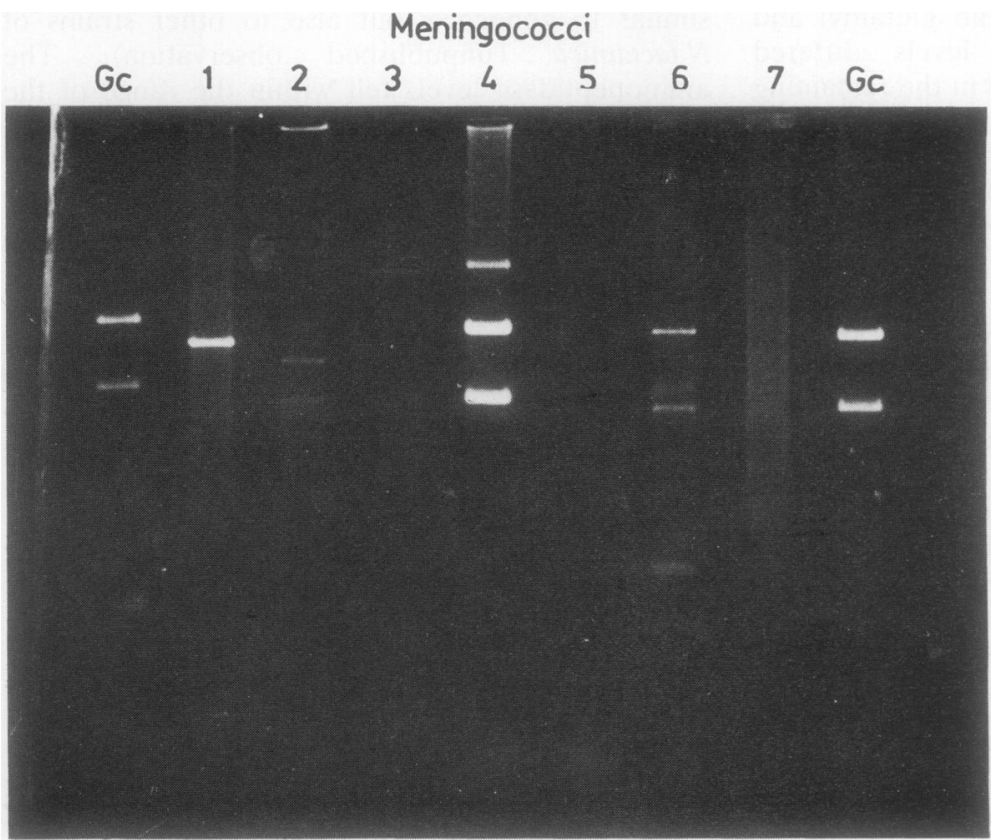

Fig. 2 Restriction fragment patterns obtained after digestion of plasmid DNA with endonuclease Hinf 1 from $N$ gonorrhoeae strain $140(G c)$, $N$ lactamica strain 160 (1), and N meningitidis strains 69 (2), 189 (3), 715 (4), 009 (5), 842 (6) and 407 (7). 
evidence was also consistent with the hypothesis that a small number of throat meningococci could originally have been oral gonococci transformed by DNA from normal mouth flora. This could lead to gonococci bearing maltase or glutamyl aminopeptidase activity, or both, and therefore to misidentification.

The presence in meningococci of a 2.6 megadalton plasmid similar to the gonococcal plasmid would have enhanced this view. However, although plasmids have been found in our throat meningococci, their relation to the gonococcal plasmid is still unclear. One possible explanation is that meningococcal strains with plasmids may have been gonococci but in accepting chromosomal DNA by transformation the 2.6 megadalton plasmid has been modified. This is unlikely because in experimental maltose positive transformants the 2.6 megadalton plasmid was retained. Alternatively, the hypothesis may be incorrect and the throat strains may be meningococci that have gained both chromosomal and plasmid DNA from other bacteria-for example, Haemophilus spp. It is also possible that technical problems are causing our inability to split these plasmids with endonucleases, and hybridisation studies will be required to resolve the relation.

The high molecular weight plasmids, $>40$ megadaltons, have been difficult to maintain and should perhaps be considered "possible" plasmids.

In recent years there have been several reports of plasmids in meningococci. The first description in a meningococcus was of a 3.4 megadalton cryptic plasmid in a strain whose source is given as "a clinical isolate". 9 A 4.8 megadalton cryptic plasmid was detected in several serogroups of $N$ meningitidis by Verschueren et al.$^{10}$ The diagnostic criteria used and the numbers and sources of the strains were not given. More recently Dekegel and Dekegel, ${ }^{11}$ using gel electrophoresis and electron microscopy, detected plasmids in most of some 40 strains of meningococci. Few details of their source were given, though both cases and carriers were involved. These findings are in striking contrast to the rarity of meningococcal plasmids generally reported in the published work. No explanation for the difference is so far available. Dillon et $a l^{12}$ found a strain of $N$ meningitidis bearing a 4.5 megadalton $\beta$ lactamase producing plasmid and a $24 \cdot 5$. megadalton transfer plasmid apparently identical to those found in gonococci. The source of the strain was uncertain, but was probably the genitourinary tract. Careful testing, including enzyme profiles, indicated a typical meningococcus.

While the finding of a penicillinase producing strain of meningococcus is a grim, if expected, warning of future therapeutic difficulties, the present work, together with the several recent descriptions of meningococcal plasmids, suggests that their scarcity is the result of limited past opportunities for spread. If so, it is not surprising that throat and, still more, genitourinary strains are the first apparent recipients. A similar occurrence has been found in genital isolates of Haemophilus infuenzae, which may carry a plasmid not usually seen at other sites. ${ }^{12}$

The use of the ortho-nitrophenyl galactoside test showed the ability to utilise lactose weakly in a few strains of meningococci. This, together with the presence of plasmids in 2/7 strains of $N$ lactamica in our study and previous reports in this species, ${ }^{4}$ also poses questions about their origin and the possibility that they may have been either gonococci or meningococci that have gained the ability to utilise lactose.

Alternatively, some of the plasmid bearing throat meningococci may be derived from strains of $\mathrm{Nlac}$ tamica which can no longer utilise lactose. More strains of all kinds need to be examined methodically. The sharp divisions produced by the simplified methods of routine diagnosis hide many nuances. The present work highlights the complexity of gene transfer within a genus and the effects it may have on identification of species and roles in infection. The possibility that acquisition of some plasmids reduces the invasiveness of $N$ meningitidis needs to be looked at.

We thank Dr AG Taylor for strains of $N$ meningitidis and Dr Henry Smith, Dr G Willshaw, and Miss SG Hadfield for help and advice. The work was supported by the Medical Research Council.

\section{References}

' Willcox RR, Spencer RC, Ison C. Which Neisseria? Br J Vener Dis $1977 ; 53: 394-7$.

${ }^{2}$ Turgeon PL, Allard R, Robert J, Turgeon F. Isolation of gonococci and meningococci in a high risk population. Abstracts of the Annual Meeting of American Society of Microbiology 1981:310.

${ }^{3}$ Ison C, Glynn AA, Bascomb S. Acquisition of new genes by oral Neisseria. J Clin Pathol 1982;35: 1153-7.

${ }^{4}$ Elwell LP, Falkow S. In: Roberts RB, ed. The Gonococcus. New York: John Wiley and Sons, 1977:137-54

s Flynn J, Watkins SA. A serum-free medium for testing fermentation reactions in Neisseria gonorrhoea. J Clin Pathol 1972;25:525-7.

- Birnboim HC, Doly. J. A rapid alkaline extraction procedure for screening recombinant plasmid DNA. Nucleic Acids Research 1979; 7: 1513-23.

${ }^{7}$ Catlin BW. Nutritional profiles of Neisseria gonorrhoeae, Neisseria Meningitidis and Neisseria lactamica in chemically defined media and the use of growth requirements for gonococcal typing. J Infect Dis 1973;128: 178-94.

${ }^{*}$ Davies JK, Normark S. A relationship between plasmid structure, structural liability and sensitivity to site-specific endonucleases in Neisseria gonorrhoeae. Mol Gen Genet 1980; 177:251-60. 
' Bhatti AR, O' Hara K, White LA, Bryan LE. Presence of plasmid deoxyribonucleic acid in Neisseria meningitidis. FEMS Microbiology Letters 1981;10:175-7.

${ }^{10}$ Verschueren H, Dekegel M, Dekegel D, Gilquin C, De Mayer S. Plasmids in Neisseria meningitidis. Lancet 1982; i:851-2.

"Dekegel M, Dekegel D. Les plasmides chez Neisseria meningitidis. Medecine Tropicale 1983;43:149-52.

12 Dillon JR, Pauze M, Yeung KH. Spread of penicillinaseproducing and transfer plasmids for the gonococcus to Neisseria meningitidis. Lancet 1983;i:779-81.
${ }^{13}$ Albritton WL, Brunton JL, Meier M, Bowman NM, Slaney LA. Haemophilus infuenzae: comparison of respiratory tract isolate with genitourinary tract isolates. J Clin Microbiol 1982; 16:826-31.

Requests for reprints to: Professor AA Glynn, Central Public Health Laboratory, 175 Colindale Avenue, London NW9 5HT, England. 